\title{
Indywidualizacja terapii hipolipemizującej drogą do obniżenia ryzyka sercowo-naczyniowego; zalecenia ekspertów, praktyczne wskazówki
}

\author{
Individualization of lipid-lowering therapy provides the tool \\ to reduce cardiovascular risk. Expert advice, practical tips
}

\author{
Katarzyna Starzyk ${ }^{1}$, Beata Wożakowska-Kapłon ${ }^{1,2}$ \\ ${ }^{1}$ I Klinika Kardiologii i Elektroterapii Świętokrzyskiego Centrum Kardiologii w Kielcach \\ ${ }^{2}$ Wydział Lekarski i Nauk o Zdrowiu Uniwersytetu Jana Kochanowskiego w Kielcach
}

\section{Streszczenie}

Podstawowym celem interwencji farmakologicznej w prewencji zdarzeń sercowo-naczyniowych (CV) jest stężenie cholesterolu frakcji LDL (IA), a podstawowa grupa leków stosowana w terapii hipolipemizującej w celu obniżenia tego stężenia to statyny (IA) zalecane w maksymalnej zarejestrowanej lub tolerowanej dawce, tak aby osiągnąć cel terapii (IA). Podsumowaniem 22 randomizowanych badań, służących analizie skuteczności i bezpieczeństwa stosowania statyn, jest metaanaliza CTT (Cholesterol Treatment Trialists'). Potwierdzono w niej korzyści ze stosowania terapii oraz osiągania celu zgodnego z aktualnymi wytycznymi. Mała skuteczność w osiąganiu celów terapeutycznych u polskich pacjentów jest, według ekspertów, związana ze stosowaniem zbyt małych dawek statyn, wyborem leku o słabym działaniu hipolipemizującym, krótkim okresem leczenia, nieuzasadnionym zaprzestaniem terapii oraz zbyt rzadkim zalecaniem terapii skojarzonej. Terapia statynami jest bezpieczna, a odsetek działań niepożądanych pozostaje niewielki. W badaniach obserwacyjnych ostatnich lat opisano objawy, których wystąpienie może skłaniać pacjenta do odstawiania statyn, takie jak: dolegliwości żołądkowo-jelitowe, zmęczenie, podwyższenie aktywności aminotransferaz, neuropatia obwodowa, bezsenność, upośledzenie funkcji poznawczych, zaburzenia neurokognitywne. W badaniach randomizowanych zauważono też niewielki wzrost ryzyka wystąpienia cukrzycy. W każdym przypadku decyzję o leczeniu statyną należy podejmować indywidualnie, po przeprowadzeniu starannej diagnostyki zgłaszanych dolegliwości i nieprawidłowości w badaniach laboratoryjnych, oraz odpowiednio dostosować dawkę. We wszystkich cytowanych zaleceniach podkreśla się, aby pochopnie nie odstawiać statyny, gdyż skutkuje to brakiem obniżenia ryzyka CV u nieleczonego pacjenta. Celem leczenia hipolipemizującego u pacjentów z rozpoznaną chorobą naczyń obarczonych bardzo wysokim ryzykiem CV, jest obniżenie stężenia cholesterolu frakcji LDL do wartości poniżej $70 \mathrm{mg} / \mathrm{dl}$ (<1,8 mmol/l). U pacjentów bez rozpoznanej choroby tętnic, nieobciążonych wysokim ryzykiem, docelowe stężenie tego parametru wynosi poniżej $100 \mathrm{mg} / \mathrm{dl}(<2,5 \mathrm{mmol} / \mathrm{l})$. Celem terapeutycznym u pacjentów z grup umiarkowanego i niskiego ryzyka jest uzyskiwanie stężenia cholesterolu frakcji LDL poniżej $115 \mathrm{mg} / \mathrm{dl}(<3,0 \mathrm{mmol} / \mathrm{l})$. Zgodnie z praktyką leczenia w Polsce, na podstawie najczęściej wybieranych dawek statyn, zaleceń ekspertów Europejskiego Towarzystwa Kardiologicznego oraz wyników przeprowadzonych w ostatnich latach badań zaleca się rozpoczynanie terapii od atorwastatyny lub rosuwastatyny, w indywidualnie dobranych dawkach, zależnie od poziomu ryzyka i stężenia cholesterolu frakcji LDL. W praktycznym zastosowaniu zaleceń może być pomocna autorska propozycja K.J. Filipiaka uwzględniająca zróżnicowanie dawek dwóch statyn, w tym atorwastatyny w dawce $60 \mathrm{mg}$ oraz rosuwastatyny w dawkach $15 \mathrm{mg}, 20 \mathrm{mg}$, 30 mg i 40 mg, w zależności od wyjściowego poziomu ryzyka. Zawsze jednak wskazówkami dotyczącymi zastosowania dawki i wyboru statyny powinny być siła jej działania oraz cel terapii wyznaczony w obowiązujących wytycznych.

Słowa kluczowe: statyny, hipercholesterolemia

Folia Cardiologica 2016; 11, 2: 140-148

Adres do korespondencji: dr n. med. Katarzyna Starzyk, I Klinika Kardiologii i Elektroterapii, Świętokrzyskie Centrum Kardiologii, ul. Grunwaldzka 45, 25-736 Kielce, e-mail: zikas@poczta.onet.pl 


\section{Wstęp}

Polska należy do krajów, w których ryzyko incydentu sercowo-naczyniowego (CV, cardiovascular) jest wysokie [1]. Zgodnie z raportem dla European Association for Prevention \& Rehabilitation średnia długość życia w ostatnich latach wynosiła 81,2 roku w przypadku kobiet (ok. 2,0 lata mniej niż średnia życia w pozostałych krajach Unii Europejskiej [UE] w porównywalnym okresie) i 72,7 roku w przypadku kobiet mężczyzn (ok. 4,7 roku mniej niż w pozostałych krajach UE) [2]. W Polsce standaryzowany współczynnik zgonów z przyczyn CV stopniowo się obniżał od 1991 roku, wynosząc w 2012 roku 48\%. Mimo to współczynnik ten niezmiennie pozostawał na poziomie aż o 50\% wyższym niż średni współczynnik w krajach UE (o 43\% wyższy u kobiet i o 58\% wyższy u mężczyzn) [1, 3].

Za występowanie choroby wieńcowej i udarów mózgu - głównych przyczyn zgonów CV - odpowiada przede wszystkim miażdżyca tętnic. W prewencji pierwotnej i wtórnej zdarzeń CV należy ograniczać znane od lat podstawowe czynniki ryzyka jej wystąpienia. W polskiej populacji (zgodnie z wynikami badania NATPOLL 2011) stwierdza się występowanie hipercholesterolemii u $61 \% \mathrm{tj}$. u 18 mln Polaków, nadciśnienia tętniczego - u 32\% (35\% mężczyzn i 29\% kobiet), otyłości - u 22\% (24\% mężczyzn i 20\% kobiet), nikotynizmu - u 27\% (31\% mężczyzn, 21\% kobiet), a cukrzycy typu 2-u 7\% (7\% mężczyzn i 6\% kobiet) osób [3, 4]. W badaniu WOBASZ hipercholesterolemia, zdefiniowana jako stężenie cholesterolu całkowitego przekraczające $193 \mathrm{mg} / \mathrm{dl} \mathrm{(>5} \mathrm{mmol} / \mathrm{l}$ ) lub cholesterolu frakcji LDL (low-density lipoprotein) wynoszące ponad $115 \mathrm{mg} / \mathrm{dl}$ (> 3 mmol/l), występowały u 67\% mężczyzn i u 64\% kobiet, a hipertriglicerydemia (stężenie triglicerydów > 150 mg/dl [> 1,7 mmol]) - u 31\% mężczyzn i 20\% kobiet [5].

W latach 2002-2011 stwierdzono w Polsce zmniejszenie liczby zgonów związanych z chorobą wieńcową i udarami mózgu. W badaniu NATPOL PLUS oszacowano, że na tę korzystną zmianę wpłynęły głównie (w 54\%) zmiana stylu życia Polaków oraz dynamiczny rozwój metod leczenia miażdżycy tętnic wieńcowych (w 37\%). Rezultatem zmian dotyczących stylu życia w największym stopniu było zmniejszenie średniego stężenia cholesterolu (obniżenie ryzyka o 41\% u mężczyzn i o 33\% u kobiet) [5]. Obliczono, że aż 85\% tej redukcji jest zasługą stosowania statyn. Gdyby stosowano wyłącznie postępowanie niefarmakologiczne, to obniżenie ryzyka CV wynosiłoby 3\% w całej dorosłej populacji badanej w 2011 roku i 6\% u pacjentów w wieku 60-79 lat [5].

\section{Skuteczność leczenia statynami}

Podstawowym celem interwencji farmakologicznej w prewencji zdarzeń CV jest stężenie cholesterolu frakcji LDL (klasa zaleceń I, poziom wiarygodności danych A), a podstawową grupą leków stosowaną w terapii hipolipemizu- jącej w celu obniżenia stężenia cholesterolu tej frakcji są statyny (IA) stosowane w maksymalnej zarejestrowanej lub tolerowanej dawce, tak aby osiągnąc cel terapii (IA) [6]. Statyny należą do leków najczęściej przepisywanych w krajach uprzemysłowionych. W 2011 roku stosowało je $11 \%$ wszystkich pacjentów badanych w ramach projektu NATPOL 2011 i niemal 32\% osób w wieku 60-79 lat [3, 4]. Podsumowaniem 22 randomizowanych badań, w których analizowano skuteczność i bezpieczeństwo stosowania statyn, jest metaanaliza CTT. Potwierdzono w niej korzyści $z$ tej terapii oraz osiaggania celu zgodnego z aktualnymi wytycznymi. Wykazano, że leczenie statyną zmniejsza śmiertelność całkowitą o 10\%, śmiertelność z przyczyn CV - o 20\%, ryzyko wystąpienia poważnych zdarzeń sercowych - o 23\%, a udarów mózgu - o 17\%, przy obniżeniu stężenia cholesterolu frakcji LDL o każdy $1 \mathrm{mmol} / \mathrm{l}$ [7]. Obniżenie ryzyka CV występowało już w 1. roku leczenia, niezależnie od wyjściowej wartości cholesterolu frakcji LDL i płci pacjentów [7].

Aby skutecznie leczyć hipercholesterolemię, należy indywidualnie, dla każdego pacjenta, wybrać optymalny lek i jego dawkę. Wśród respondentów badania NATPOL 2011 tylko 8\% osób z hipercholesterolemią było skutecznie leczonych hipolipemizująco. W rejestrze 3ST-Pol, z lat 2007-2008, stosując u pacjentów z grupy wysokiego ryzyka CV małe dawki statyn (20 mg simwastatyny lub $20 \mathrm{mg}$ atorwastatyny), osiągnięto docelowe (wówczas wynoszące $<80 \mathrm{mg} / \mathrm{dl}$ [2,1 mmol/l]) wartości cholesterolu frakcji LDL u 5,6\% badanych. W badaniu POLKARD-SPOK (lata 2003-2005) docelową wartość tego parametru osiągało 11,6\% leczonych pacjentów z hipercholesterolemią [3, 8]. W badaniu ankietowym przeprowadzonym w polskich poradniach kardiologicznych w 2015 roku 90\% pacjentów rozpoczynających leczenie otrzymywało statynę (głównie atorwastatynę i simwastatynę), tym niemniej stężenie cholesterolu frakcji LDL poniżej $100 \mathrm{mg} / \mathrm{dl}$ (2,5 mmol/l) uzyskiwało $27 \%$, a poniżej $70 \mathrm{mg} / \mathrm{dl}$ (1,8 mmol/l) - jedynie $10 \%$ pacjentów [9]. Mała skuteczność w osiąganiu celów terapeutycznych u polskich pacjentów jest, według ekspertów, związana ze stosowaniem zbyt małych dawek statyn, wyborem leku o słabym działaniu hipolipemizującym, krótkim okresem leczenia, nieuzasadnionym zaprzestaniem terapii oraz zbyt rzadkim stosowaniem terapii skojarzonej [3]. Stężenie cholesterolu frakcji LDL przekraczające $70 \mathrm{mg} / \mathrm{dl}$ (1,8 mmol/l) stwierdzano u 73\% pacjentów z już rozpoznaną chorobą układu $\mathrm{CV}, \mathrm{tj}$. obciążonych wysokim ryzykiem CV, w okresie 6-18 miesięcy po ostrym zespole wieńcowym. Wykazano również, że pacjenci po zawale serca odstawiają jeden zalecany lek (w tym najczęściej statynę) w ciągu pierwszych 6 miesięcy po hospitalizacji [10]. Odstawienie statyny lub nieskuteczne leczenie niesie ze sobą niekorzystne skutki. W metaanalizie badań obserwacyjnych oszacowano, że odstawienie statyny wiąże się ze zwiększeniem częstości występowania incydentów CV 
i zwiększeniem śmiertelności w porównaniu z osobami kontynuującymi zalecaną terapię [11].

Jest wiele powodów odstawiania leków hipolipemizujących, głównie statyn, przez pacjenta; czasem przyczyną są negatywne informacje dostępne w mediach. W badaniu duńskim, obejmującym lata 1995-2010, częstość przerywania leczenia głównie pod wpływem doniesień w prasie, programach radiowych i telewizyjnych, wzrosła od $6 \%$ do 18\%. U pacjentów zaprzestających leczenia zwiększyła się częstość występowania zawałów serca w porównaniu z kontynuującymi terapię (współczynnik ryzyka [HR, hazard ratio] 1,26 (95-proc. przedział ufności [Cl, confidence interval] 1,21-1,30), zwiększyła się również częstość zgonów z przyczyn CV. Częstość odstawiania leków pod wpływem informacji w mediach była większa w przypadku mężczyzn, mieszkańców miast i innej niż duńska narodowości, przyjmujących większe dawki leków [12]. Za niedostateczne obniżanie stężenia cholesterolu odpowiada również inercja terapeutyczna lekarzy i zalecanie przez nich zbyt małych dawek statyn [3].

\section{Bezpieczeństwo leczenia statynami}

W badaniach obserwacyjnych z ostatnich lat opisano też objawy, których wystąpienie może skłaniać pacjenta do odstawiania statyn, takie jak: dolegliwości żołądkowo-jelitowe, zmęczenie, podwyższenie aktywności aminotransferaz, neuropatia obwodowa, bezsenność, upośledzenie funkcji poznawczych, zaburzenia neurokognitywne. W badaniach randomizowanych zauważono także niewielki wzrost ryzyka wystąpienia cukrzycy. Rejestry pacjentów i doświadczenie kliniczne wskazują, że najczęściej zgłaszanymi dolegliwościami są objawy mięśniowe, występujące ogółem u 7-29\% osób. W większości przypadków, u 5-10\% pacjentów leczonych statynami, współistnieją one z prawidłową lub nieznacznie podwyższoną aktywnością kinazy kreatynowej (CK, creatine kinase). Groźnym w skutkach, ale występującym sporadycznie, powikłaniem $(<0,01 \%$ leczonych statyną), jest rabdomioliza prowadząca do uszkodzenia nerek w wyniku uwalniania z mięśni mioglobiny. Eksperci zalecają, aby w przypadku wystąpienia dolegliwości związanych ze stosowaniem statyn przeprowadzić wnikliwy proces diagnostyczny, wybrać optymalną dawkę silnie działającej statyny i najkorzystniejszy dla pacjenta sposób dawkowania (np. co 2-3 dni), dążąc do osiągnięcia celu terapii (odpowiednie do ryzyka CV obniżenie cholesterolu frakcji LDL) przy jednoczesnej dobrej tolerancji leku (ryc. 1) [13].

Terapia statynami jest bezpieczna, a odsetek działań niepożądanych pozostaje niewielki. Tym niemniej, stosując statyny, należy zadbać o ograniczenie wpływu czynników zwiększających prawdopodobieństwo wystąpienia działań niepożądanych (zwłaszcza u kobiet, osób w podeszłym wieku i z małą masą ciała). Do takich czynników należą: niedoczynność tarczycy, nadużywanie alkoholu, upośledzona funkcja nerek lub wątroby, choroba wieloukładowa, jednoczesne przyjmowanie innych leków, takich jak: gemfibrozil, antybiotyki makrolidowe, leki przeciwgrzybicze z grupy konazoli, warfaryna, werapamil, fluoksetyna, inhibitory proteazy ludzkiego wirusa niedoboru odporności (HIV, human immonodeficiency virus), amiodaron. Dawka simwastatyny nie powinna przekraczać $10 \mathrm{mg} /$ dobę w przypadku jednoczesnego stosowania cyklosporyny, danazolu, gemfibrozilu lub innych fibratów (z wyjątkiem fenofibratu), $20 \mathrm{mg} /$ dobę w przypadku jednoczesnego stosowania amiodaronu lub werapamilu oraz $40 \mathrm{mg} /$ dobę w przypadku jednoczesnego stosowania diltiazemu, a w ogóle nie powinno się jej podawać, jeśli pacjent pija sok grejfrutowy. W większości przypadków podczas występowania dolegliwości bólowych mięśni stężenie CK pozostaje niezmienione. Jeżeli obserwuje się niewielki ( $4 \times$ powyżej górnej granicy normy [ULN, upper limit of normal]) wzrost wartości CK, ale nasilenie objawów jest akceptowane przez pacjenta, to terapię statyną można kontynuować $[5,13]$. Jeśli dolegliwości nie ustępują, to stosowaną statynę należy zamienić na inną lub zastosować dawkowanie co dwa dni lub nawet 2-3 razy w tygodniu, tak aby osiągnąć docelową redukcję wartości cholesterolu frakcji LDL. Odstawienie stosowanej dotychczas statyny jest uzasadnione w przypadku podwyższenia aktywności CK 4-krotnie powyżej ULN [13]. Po normalizacji wyników badań biochemicznych należy zastosować terapię inną statyną. Najniższe ryzyko miopatii występuje przy stosowaniu rosuwastatyny, co wynika z jej odmiennego metabolizmu. Należy indywidualnie dobierać substancję i jej dawkę, pamiętając o osobniczej zmienności odpowiedzi na leczenie (różnice 10-70\%), tak aby osiągnąć cel terapii, a następnie kontynuować leczenie w ustalonej dawce [13].

Terapia statynami może wywołać podwyższenie aktywności aminotransferaz wątrobowych. W metaanalizach badań randomizowanych, w tym CTT, nie analizowano podwyższenia enzymów wątrobowych, u pacjentów przyjmujących statyny [7]. Podwyższenie aminotransferaz wątrobowych stwierdzano w badaniach randomizowanych u 0,5-2,0\% pacjentów leczonych statynami i zależało od dawki leku. Progresja do niewydolności wątroby występuje niezmiernie rzadko [14]. Cofnięcie się podwyższenia wartości transaminaz często obserwuje się po zmniejszeniu dawki statyny. Eksperci Europejskiego Towarzystwa Kardiologicznego (ESC, European Society of Cardiology) zalecają oznaczenie aktywności aminotransferazy alaninowej (ALT, alanine aminotransferase) wstępnie, następnie 8 tygodni po rozpoczęciu leczenia lub po każdym zwiększeniu dawki, a także co roku. Jeśli aktywność ta nie przekracza 3-krotnie ULN, to leczenie należy kontynuować, wykonując kontrolę po upływie 4-6 tygodni. Za istotne uznano zwiększenie aktywności ALT 3-krotnie przekraczające ULN, potwierdzone w kolejnym oznaczeniu. Jeśli wzrost aktywności transaminaz będzie się utrzymywać ponad 3-krotnością ULN lub będzie jeszcze większy, to należy przerwać 


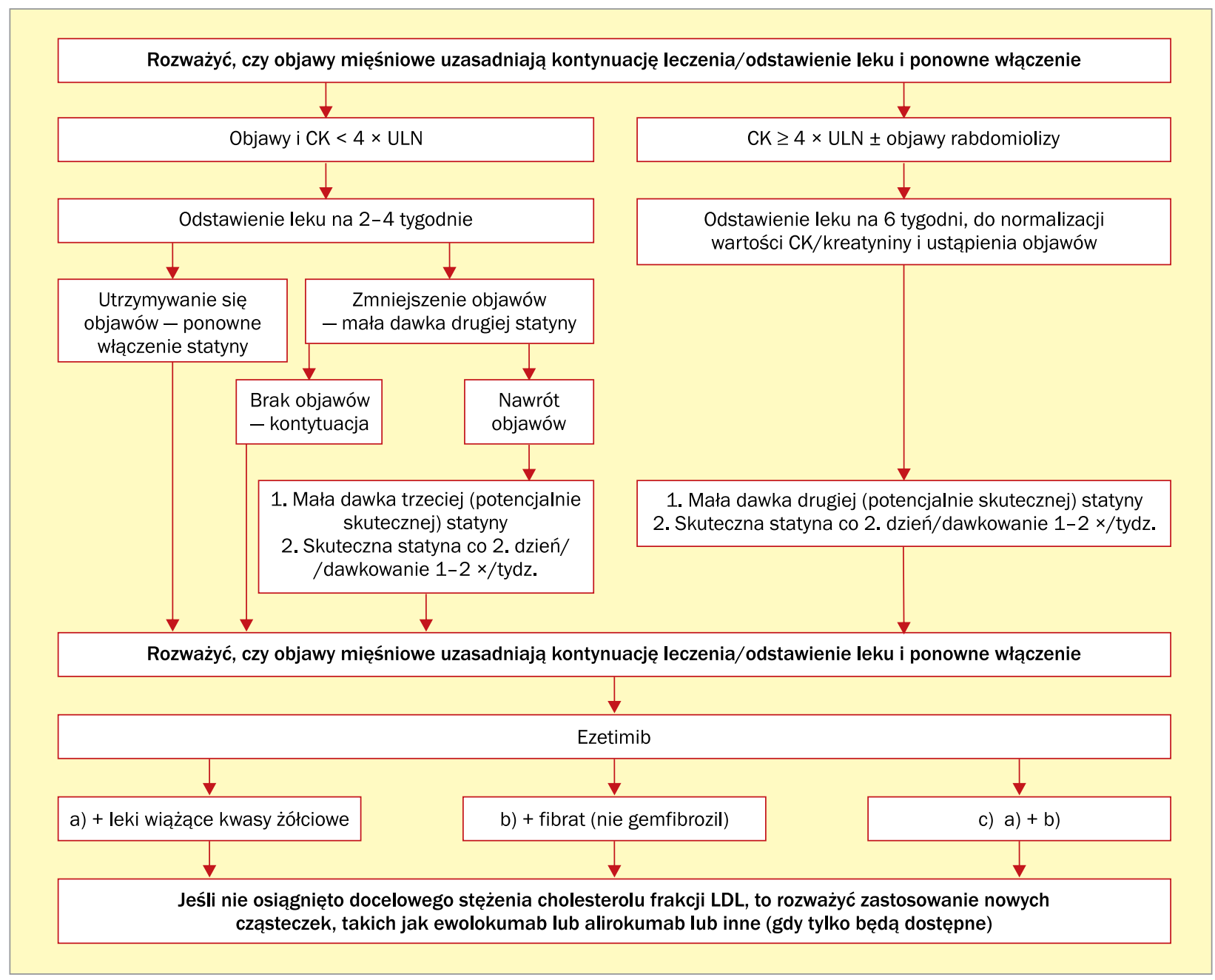

Rycina 1. Algorytm postępowania w przypadku wystąpienia objawów mięśniowych podczas leczenia statyną (przedrukowano za zgodą z [13])

leczenie lub zmniejszyć dawkę statyny, a następnie skontrolować ALT w ciągu 4-6 tygodni. Pacjent powinien być obserwowany, a aktywność ALT monitorowana do czasu ustąpienia nieprawidłowości. Równocześnie należy szukać innych przyczyn, takich jak spożycie alkoholu lub niealkoholowa stłuszczeniowa choroba wątroby. Jeśli stężenia pozostają podwyższone, to statynę należy odstawić, ale można podjąć ostrożną, ponowną próbę jej włączenia przy zachowaniu monitorowania aktywności enzymów po powrocie ich wartości do prawidłowych. Można rozważyć ponowne rozpoczęcie leczenia po normalizacji ALT [6]. Przeciwwskazaniem do stosowania statyn są jedynie ostra niewydolność wątroby i zdekompensowana marskość wątroby (skompensowanych schorzeń nie uznaje się za bezwzględne przeciwwskazanie do terapii statynami). Nie należy stosować statyny u pacjenta z czynną chorobą wątroby, zwiększoną aktywnością aminotransferaz w surowicy i ponad 3-krotnym zwiększeniem powyżej ULN aktywności jednej z nich (po potwierdzeniu nieprawidłowości w badaniu kontrolnym) [6]. W raporcie amerykańskiej grupy
Statin Liver Task Force, opublikowanym w 2015 roku, podkreślono, że występowanie ciężkich stanów związanych z leczeniem statynami, takich jak niewydolność wątroby, jest bardzo rzadkie. Eksperci uważają, że statyny można stosować u pacjentów ze stabilnym, niepowikłanym przebiegiem schorzeń wątroby, takich jak: niealkoholowa choroba stłuszczeniowa wątroby, przewlekłe zapalenie wątroby typu B i C, autoimmunologiczne zapalenia wątroby, a nawet u pacjentów po transplantacji wątroby [14]. W każdym przypadku należy jednak indywidualnie podejmować decyzję o leczeniu statyną, po przeprowadzeniu starannej diagnostyki stanu zaawansowania określonego schorzenia, a także odpowiednio dostosować dawkę [14]. Niektóre statyny, w tym atorwastatyna i simwastatyna, są metabolizowane w wątrobie przy udziale izoenzymu cytochromu P450 (CYP3A4), co może zwiększać prawdopodobieństwo podwyższenia aktywności ALT, zwłaszcza uosób leczonych z powodu schorzeń wątroby. Rosuwastatyna jedynie w niewielkiej części $(<10 \%)$ jest metabolizowana w układzie cytochromu P450, co oznacza, że wykazuje dużo mniejszy 
potencjał wywoływania interakcji z innymi lekami, stanowi więc optymalny wybór między innymi u pacjentów ze schorzeniami wątroby [7].

Zaburzenia funkcji nerek u pacjenta z hipercholesterolemią stanowią kolejną sytuację kliniczną wpływającą na wybór leku hipolipemizującego. W metaanalizach wykazano korzystne, istotne spowolnienie spadku przesączania kłębuszkowego (GFR, glomerular filtration rate) podczas leczenia atorwastatyną. Porównawcza ocena wpływu atorwastatyny i rosuwastatyny na przesączanie kłębuszkowe u chorych na cukrzycę i z przewlekłą chorobą nerek w randomizowanym badaniu klinicznym PLANET I wykazała korzystniejszy profil bezpieczeństwa atorwastatyny w tej grupie chorych [15]. Ciężkie zaburzenia funkcji nerek (GFR $<30 \mathrm{ml} / \mathrm{min}$ ) stanowią przeciwwskazanie do podawania rosuwastatyny (ChPL). Eksperci zalecają, aby nie stosować rosuwastatyny w dawce ponad $30 \mathrm{mg}$ u chorych z umiarkowaną i ciężką chorobą nerek (klirens kreatyniny $<60 \mathrm{ml} / \mathrm{min}$ ) [16]. We wszystkich cytowanych zaleceniach podkreśla się, aby pochopnie nie odstawiać statyny, gdyż skutkuje to brakiem redukcji ryzyka CV u nieleczonego pacjenta $[5,6,14]$.

\section{Najważniejsze różnice między statynami}

Spośród statyn o sile działania pozwalającej osiągnąć docelowe stężenie cholesterolu frakcji LDL eksperci proponują stosowanie rosuwastatyny i atorwastatyny [5]. Ze względu na fakt syntezy cholesterolu przez organizm ludzki we wczesnych godzinach porannych oraz krótki okres półtrwania leku $\left(\mathrm{T}_{1 / 2}\right)$ simwastatyna $\left(\mathrm{T}_{1 / 2}<5 \mathrm{~h}\right)$ powinna być stosowana w godzinach wieczornych. Natomiast atorwastatyna i rosuwastatyna mogą być stosowane w ciągu całej doby ze względu na długie okresy półtrwania, które wynoszą, odpowiednio, 14 (aktywne metabolity atorwastatyny 20-30 h) i 19 godzin [17]. Zarówno między poszczególnymi substancjami, jak i ich preparatami występują różnice w zakresie biodostępności, wchłaniania, wiązania z białkami czy sposobu wydalania. Simwastatyna i lowastatyna są prolekami, pozostałe zaś - substancjami aktywnymi. Wyniki badania SEARCH spowodowały wycofanie rekomendacji amerykańskiej Agencji ds. Żywności i Leków (FDA, Food and Drug Administration) dla simwastatyny w dawce $80 \mathrm{mg}$ ze względu na na zwiększone ryzyko rozwoju miopatii [8].

\section{Strategia leczenia hipercholesterolemii}

Zgodnie z obowiązującymi zaleceniami ESC i Polskiego Towarzystwa Kardiologicznego (PTK), dotyczącymi leczenia dyslipidemii, w pierwszej kolejności należy przeprowadzić analizę indywidualnego ryzyka CV [18]. Na podstawie badań NATPOL opracowano tabelę ryzyka POL-SCORE dla polskiej populacji (www.ptkardio.pl/Uaktualniona wersja oceny ryzyka CV PolSCORE_2015-2459) (ryc. 2) [19].
Ryzyko CV określa się jako: bardzo wysokie, wysokie, umiarkowane lub niskie. Bardzo wysokim ryzykiem są obarczeni pacjenci z chorobą układu CV lub jej epidemiologicznym ekwiwalentem - cukrzycą typu 1 lub 2, w przypadku współistnienia jednego lub większej liczby dodatkowych czynników ryzyka CV lub uszkodzenia narządowego, przewlekłą chorobą nerek (CKD, chronic kidney disease) z GFR poniżej $30 \mathrm{ml} / \mathrm{min} / 1,73 \mathrm{~m}^{2}$ oraz osoby z wyliczonym 10-procentowym lub wyższym ryzykiem zgonu CV w ciągu 10 lat według karty SCORE. Kolejny poziom ryzyka, tj. wysokie, występuje u osób z ciężkim nadciśnieniem tętniczym, cukrzycą bez dodatkowych czynników ryzyka i uszkodzeń narządowych, chorych na CKD z GFR $30-59 \mathrm{ml} / \mathrm{min} / 1,73 \mathrm{~m}^{2}$ oraz obarczonych ryzykiem zgonu 5-9\% według karty SCORE. Osoby z wyliczonym wynikiem poniżej 5\% według karty SCORE osiągają poziom ryzyka umiarkowanego i niskiego $[19,20]$.

Celem leczenia hipolipemizującego u pacjentów z rozpoznaną chorobą naczyń, cechujących się bardzo wysokim ryzykiem CV, jest obniżenie stężenia cholesterolu frakcji LDL do wartości poniżej $70 \mathrm{mg} / \mathrm{dl}(<1,8 \mathrm{mmol} / \mathrm{l})$. U pacjentów bez rozpoznanej choroby tętnic, z grupy wysokiego ryzyka, docelowe stężenie cholesterolu wynosi mniej niż $100 \mathrm{mg} / \mathrm{dl}$ (<2,5 mmol/l). Celem terapeutycznym u pacjentów z grup umiarkowanego i niskiego ryzyka jest uzyskiwanie stężenia cholesterolu frakcji LDL poniżej $115 \mathrm{mg} / \mathrm{dl}$ (<3,0 mmol/l) [20].

Jedną z przyczyn hipercholesterolemii (1:500-1:700) w polskiej populacji jest uwarunkowana genetycznie heterozygotyczna hipercholesterolemia rodzinna $(\mathrm{FH}$, familial hypercholesterolaemia). Wszystkie osoby z FH są obarczone wysokim ryzykiem CV, a w przypadku obecności objawowej choroby CV - bardzo wysokim ryzykiem CV. Hipercholesterolemię rodzinną rozpoznaje się na podstawie zaadaptowanych do warunków polskich kryteriów punktowej skal The Dutch Lipid Clinic Network-WHO i Simone Broome Register. Kryteria kliniczne rozpoznania FH obejmują stężenie cholesterolu frakcji LDL w osoczu (3 pkt. przy stężeniu cholesterolu frakcji LDL > $190 \mathrm{mg} / \mathrm{dl}$ [> 5,0 mmol/l]), obecność rąbka rogówkowego i żółtaków ścięgien, przedwczesną chorobę układu CV oraz dodatni wywiad rodzinny w kierunku hipercholesterolemii i przedwczesnej choroby układu CV. W zaleceniach polskich ekspertów podkreślono, że jest możliwe ustalenie klinicznego rozpoznania $\mathrm{FH}$ bez badania genetycznego, a uzyskanie co najmniej 5 puktów wyliczonych na podstawie skali punktowej stanowi wystarczające uzasadnienie dla leczenia refundowanego ze środków publicznych. U chorego z rozpoznaniem FH celem terapii jest osiągnięcie stężenia cholesterolu frakcji LDL poniżej $100 \mathrm{mg} / \mathrm{dl}$, a w przypadku występowania objawowej choroby naczyniowej - poniżej $70 \mathrm{mg} / \mathrm{dl}$ [21].

Przełomowym badaniem, wskazującym na korzystny efekt znacznego obniżania stężenia cholesterolu frakcji LDL, było IMPROVE-IT (IMProved Reduction of Outcomes: 


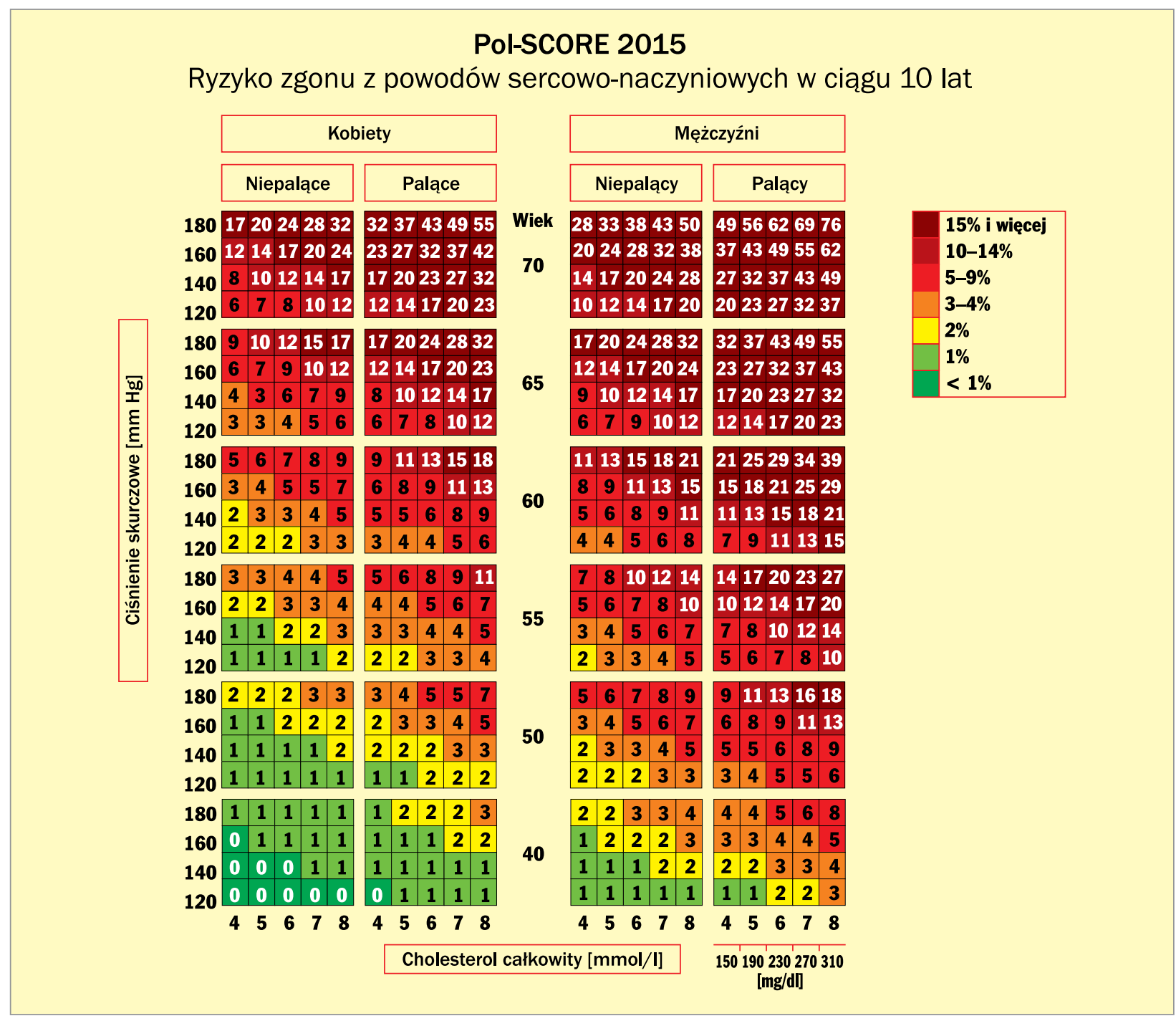

Rycina 2. Tablica ryzyka SCORE - 10-letnie ryzyko zgonu z powodu chorób układu sercowo-naczyniowego w krajach o wysokim ryzyku sercowo-naczyniowym (źródło [19])

Vytorin Efficacy International Trial). Wykazano w nim, że najlepsze rokowanie cechuje chorych, u których stężenie cholesterolu LDL obniżono do wartości poniżej $55 \mathrm{mg} / \mathrm{dl}$ (<1,5 mmol/l) Stosowane leczenie było bezpieczne dla pacjentów - częstość występowania objawów niepożądanych oraz chorób nowotworowych w obu grupach była porównywalna [22]. W opublikowanej w 2014 roku metaanalizie badań, w których leczeniu statyną poddano 38153 pacjentów, stwierdzono 56-procentowe obniżenie całkowitego ryzyka CV w grupie osiągającej stężenie cholesterolu frakcji LDL poniżej $50 \mathrm{mg} / \mathrm{dl}$, tj. 1,3 mmol/l ( $\mathrm{m}=4375)$, co w odniesieniu do cholesterolu stanowi potwierdzenie zasady „im niżej, tym lepiej”. Zaobserwowano również 53-procentową redukcję liczby incydentów wieńcowych i 64-procentową redukcję liczby incydentów udarowych, w porównaniu z pacjentami leczonymi nieskutecznie [23].

\section{Indywidualizacja dawek statyn}

Zgodnie z tak zwana regułą Robertsa podwojenie dawki statyny skutkuje dalszym obniżeniem wartości cholesterolu frakcji LDL o 7\%. Najsilniejszą z dostępnych w Polsce statyn jest rosuwastatyna, zalecana jako lek z wyboru w przypadku nieosiągania celu terapeutycznego podczas leczenia słabszymi statynami $[3,6,8,20]$. Wyliczenie ekwipotencjalnych dawek satatyn przedstawione w tabeli według Robertsa nie ma zastosowania dla rosuwastatyny, której siła działania jest nie 2-, ale 3-krotnie większa od siły działania atorwastatyny.

W polskich badaniach epidemiologicznych, cytowanych powyżej, najczęściej stosowanymi dawkami statyn były $20 \mathrm{mg}$ simwastatyny i $20 \mathrm{mg}$ atorwastatyny [9]. Osiąganie zalecanych w wytycznych niskich stężeń cholesterolu frakcji 
Tabela 1. Obniżenie stężeń cholesterolu frakcji LDL (low-density lipoprotein) w badaniu ROSU-PATH (źródło [25])

$\begin{array}{lccc} & \text { Obniżenie stężenia cholesterolu LDL w } & \text { przypadku zastosowania rosuwastatyny (\%) } \\ \text { Czas obserwacji (tyg.) } & 4 & 8 & 12 \\ \text { Grupa 1. (dawki: } 10 \text { mg, } 20 \text { mg, } 40 \text { mg) } & 40,7 & 45,7 & 51,3 \\ \text { Grupa 2. (dawki: } 15 \text { mg, } 30 \text { mg, } 40 \text { mg) } & 49,0 & 49,8 & 48,1\end{array}$

Tabela 2. Strategie interwencji w zależności od całkowitego ryzyka oraz aktualnego stężenia cholesterolu frakcji LDL (low-density lipoprotein) (źródło [25])

\begin{tabular}{|c|c|c|c|c|c|}
\hline \multirow{2}{*}{$\begin{array}{l}\text { Całkowite } \\
\text { ryzyko sercowo- } \\
\text {-naczyniowe wg } \\
\text { SCORE }\end{array}$} & \multicolumn{5}{|c|}{ Stężenie cholesterolu frakcji LDL [mg/dl (mmol/l)] } \\
\hline & $<70(<1,8)$ & $\begin{array}{c}70 \text { do }<100 \\
(1,8 \text { do }<2,5)\end{array}$ & $\begin{array}{l}100 \text { do }<155 \\
(2,5 \text { do }<4,0)\end{array}$ & $\begin{array}{l}155 \text { do }<190 \\
(4,0 \text { do }<4,9)\end{array}$ & $>190(>4,9)$ \\
\hline$<1$ & $\begin{array}{c}\text { Bez } \\
\text { interwencji }\end{array}$ & Bez interwencji & Zmiana stylu życia & Zmiana stylu życia & $\begin{array}{l}\text { Zmiana stylu życia, } \\
\text { w przypadku niepowo- } \\
\text { dzenia rozważ R15 }\end{array}$ \\
\hline$\geq 1<5$ & $\begin{array}{c}\text { Zmiana } \\
\text { stylu życia }\end{array}$ & Zmiana stylu życia & $\begin{array}{l}\text { Zmiana stylu życia, } \\
\text { w przypadku niepowo- } \\
\text { dzenia rozważ A40 }\end{array}$ & $\begin{array}{l}\text { Zmiana stylu życia, } \\
\text { w przypadku niepowo- } \\
\text { dzenia rozważ R15 }\end{array}$ & $\begin{array}{l}\text { Zmiana stylu życia, } \\
\text { w przypadku niepowo- } \\
\text { dzenia rozważ R20 }\end{array}$ \\
\hline$\geq 5<10$ & $\begin{array}{l}\text { Zmiana } \\
\text { stylu życia, } \\
\text { rozważ A20 }\end{array}$ & $\begin{array}{l}\text { Zmiana stylu życia, } \\
\text { rozważ A30 }\end{array}$ & $\begin{array}{c}\text { Zmiana stylu życia } \\
\text { oraz natychmiastowo } \\
\text { R15 }\end{array}$ & $\begin{array}{c}\text { Zmiana stylu życia } \\
\text { oraz natychmiastowo } \\
\text { R20 }\end{array}$ & $\begin{array}{c}\text { Zmiana stylu życia oraz } \\
\text { natychmiastowo R30 }\end{array}$ \\
\hline $\begin{array}{l}\geq 10 \text { lub bar- } \\
\text { dzo wysokie } \\
\text { ryzyko }\end{array}$ & $\begin{array}{c}\text { Zmiana } \\
\text { stylu życia, } \\
\text { rozważ A30 }\end{array}$ & $\begin{array}{c}\text { Zmiana stylu życia } \\
\text { oraz natychmiasto- } \\
\text { wo A60 }\end{array}$ & $\begin{array}{c}\text { Zmiana stylu życia } \\
\text { oraz natychmiastowo } \\
\text { R20 }\end{array}$ & $\begin{array}{c}\text { Zmiana stylu życia } \\
\text { oraz natychmiastowo } \\
\text { R30 }\end{array}$ & $\begin{array}{c}\text { Zmiana stylu życia oraz } \\
\text { natychmiastowo R40 }\end{array}$ \\
\hline
\end{tabular}

LDL jest możliwe dzięki zastosowaniu rosuwastatyny bądź atorwastatyny. W badaniu ROSU-PATH (The Efficacy and Safety of ROSUvastatin Dose Titration in the Treatment of PATients with Hyperlipidemia) około 500 pacjentów z grupy wysokiego ryzyka CV, stosujących rosuwastatynę w prewencji pierwotnej i wtórnej, podzielono na grupy pierwszą, przyjmującą wzrastające dawki: $10 \mathrm{mg}, 20 \mathrm{mg}$, 40 mg, i drugą, której podawano większe początkowo dawki leku, odpowiednio: $15 \mathrm{mg}, 30 \mathrm{mg}, 40 \mathrm{mg}$. Co 4 tygodnie zwiększano dawkę (zgodnie z zaplanowanym w protokole badania sposobem określonym dla każdej z grup), aż do osiągnięcia celu terapeutycznego, definiowanego jako stężenie cholesterolu frakcji LDL (zgodnego z wytycznymi ESC z 2011 r.), po czym leczenie kontynuowano w skutecznej, niezmienianej do końca badania dawce [24]. W 12. tygodniu w grupie pierwszej uzyskano następujące obniżenie stężenia cholesterolu frakcji LDL: dla $10 \mathrm{mg}$ - o 40,7\%, dla $20 \mathrm{mg}$ - o 45,7\%, a dla $40 \mathrm{mg}$ - o 51,3\%. W grupie drugiej uzyskano większy stopień redukcji wartości cholesterolu frakcji LDL, wynoszący: dla dawki $15 \mathrm{mg}$ - 49,0\%, dla $30 \mathrm{mg}-49,8 \%$ i porównywalny z osiągniętym w grupie pierwszej dla dawki $40 \mathrm{mg}-48,1 \%$ [25] (tab. 1).

Na podstawie praktyki leczenia stosowanej w Polsce, najczęściej wybieranych dawek statyn, zaleceń ekspertów ESC oraz wyników przeprowadzonych w ostatnich latach badań zaleca się rozpoczynanie terapii od atorwastatyny lub rosuwastatyny, w indywidualnie dobranych dawkach, zależnie od poziomu ryzyka i stężenia cholesterolu frakcji LDL. W praktycznym zastosowaniu zaleceń pomocna może być autorska propozycja Krzysztofa J. Filipiaka uwzględniająca zróżnicowanie dawek dwóch statyn, w tym $60 \mathrm{mg}$ atorwastatyny oraz $15 \mathrm{mg}, 20 \mathrm{mg}, 30 \mathrm{mg}$ i $40 \mathrm{mg}$ rosuwastatyny, w zależności od wyjściowego poziomu ryzyka (tab. 2). Zawsze jednak wskazówkami dotyczącymi zastosowania dawki i wyboru statyny powinny być jej siła działania oraz cel terapii wyznaczony w obowiązujących wytycznych.

Podstawowym celem terapii hipolipemizującej jest osiąganie i utrzymywanie docelowego stężenia cholesterolu frakcji LDL określonego w wytycznych. Takie rekomendacje mają najwyższą klasę zaleceń i najwyższy poziom dowodu, co oznacza, że ich realizowanie jest obowiązkowe. Niestety, w Polsce osiąganie celów terapii hipolipemizującej, określanych w wytycznych, nadal pozostaje na wstydliwie niskim poziomie. W badaniu rejestrowym przeprowadzonym w Polsce w 2015 roku przez niezależną firmę badawczą Sequence HC Partners Sp. z o.o. wykazano, że zaledwie u 11\% pacjentów z chorobą wieńcową i cukrzycą, jedynie u 11\% osób po ostrym zespole wieńcowym i tylko u 12\% pacjentów poddanych uprzednio angioplastyce wieńcowej 
bywa osiągany cel terapii, czyli stężenie cholesterolu frakcji LDL we krwi poniżej $70 \mathrm{mg} / \mathrm{dl}$ [9]. Indywidualizacja terapii hipolipemizującej oraz szersze zastosowanie pośrednich dawek statyn mogą przyczynić się do poprawy wyników terapii chorych z grup wysokiego i bardzo wysokiego ryzyka CV.

Skuteczne leczenie hipercholesterolemii wciąż pozostaje wyzwaniem. Kierowanie się w wyborze leku i jego dawki poziomem ryzyka CV oraz wprowadzanie do terapii silnie działających statyn pozwala na osiąganie zalecanych przez ekspertów stężeń cholesterolu frakcji LDL.
Zwiększenie skuteczności leczenia wraz z intensyfikacją metod niefarmakologicznych wpływających na styl życia może spowodować dalszą redukcję częstości występowania zgonów z przyczyn CV i wydłużyć życie pacjentów co najmniej do poziomu osiąganego już dziś w części krajów Unii Europejskiej.

\section{Konflikt interesów}

BWK - honoraria za wykłady dla firm: Egis, Krka, MSD, Mylan, Servier.

\section{Abstract}

The basic aim of pharmacological intervention in the prevention of cardiovascular (CV) events is LDL-cholesterol (IA). The primary group of drugs lowering LDL-cholesterol are statins (IA) used in the maximum registered or tolerated doses to achieve the goal of therapy (IA). The summary of 22 randomized trials examining the efficacy and safety of statins is the CTT (Cholesterol Treatment Trialists') meta-analysis. It confirmed the benefits of the therapy, when achieving recommended in the current guidelines LDL-cholesterol level goals. Low efficiency in achieving therapeutic goals in Polish patients is, according to experts, associated with the use of small doses of statins, the choice of drug with too weak lipid-lowering effect, short period of treatment, unjustified cessation of therapy, and not sufficiently frequent use of combination therapy. Statin therapy is safe and proportion of adverse events is low. Observational studies in recent years have described the symptoms which may lead to patient withdrawal of statins, such as gastrointestinal symptoms, fatigue, increase in transaminases, peripheral neuropathy, insomnia, cognitive impairment, and neurocognitive disorders. In randomized studies a slight increase in the risk of diabetes has been also noted. It is recommended to decide individually on statin therapy, after a careful diagnosis of the reported symptoms and laboratory abnormalities, and to adjust drug dose. It is emphasized not to discontinue statins hastily, because it results in a lack of reduction in CV risk in an untreated patient. The goal of lipid-lowering therapy in patients with a diagnosis of vascular disease, characterized by a very high risk of $\mathrm{CV}$, is to lower LDL-cholesterol to $<70 \mathrm{mg} / \mathrm{dl}(<1.8 \mathrm{mmol} / \mathrm{l})$. In patients without the vascular disorder, who are not at high risk, the target is cholesterol $<100 \mathrm{mg} / \mathrm{dl}(<2.5 \mathrm{mmol} / \mathrm{l})$. The therapeutic target for patients at moderate and low risk is getting LDL-cholesterol $<115 \mathrm{mg} / \mathrm{dl}(<3.0 \mathrm{mmol} / \mathrm{l})$. Based on clinical practice in Poland, the most popular statin doses, the recommendations of experts from the European Society of Cardiology and the results of the past years of research, it is recommended to start therapy with atorvastatin or rosuvastatin, in individually titrated doses, depending on the level of risk and LDL-cholesterol. In the practical application of the recommendations, suggestion of KJ Filipiak may be helpful. He takes into account two statins in different doses: atorvastatin $60 \mathrm{mg}$ and rosuvastatin $15 \mathrm{mg}, 20 \mathrm{mg}, 30 \mathrm{mg}$ and $40 \mathrm{mg}$, depending on the initial level of risk. The dose of the drug and choice of statin should be guided by its potency and therapeutic goals, as determined by the recommendations.

Key words: statins, cholesterol, hypercholesterolaemia

Folia Cardiologica 2016; 11, 2: 140-148

\section{Piśmiennictwo}

1. World Health Organisation Regional Office for Europe: mortality indicator database: mortality indicators by 67 causes of death, age and sex (HFA-MDB). Zaktualizowano w październiku 2015 r. Dostępne na: data.euro.who.int/hfamdb/. Data dostępu 31.03.2016 r.

2. Jankowski P. Country report Poland - June 2014. National CVD Prevention Coordinator for Poland. Prepared for the EACPR "Country of the Month" initiative. Data dostępu: 27.02.2016 r.

3. Wożakowska-Kapłon B., Filipiak K., Mamcarz A. i wsp. Aktualne problemy dyslipidemii w Polsce - II Deklaracja Sopocka. Stanowisko grupy ekspertów wsparte przez Sekcję Farmakoterapii Sercowo-Naczynio- wej Polskiego Towarzystwa Kardiologicznego. Kardiol. Pol. 2014; 72: 847-853.

4. Zdrojewski T., Solnica B., Cybulska B. i wsp. Prevalence of lipid abnormalities in Poland. The NATPOL 2011 survey. Kardiol. Pol. 2016; 74: 213-223.

5. Bandosz P., O'Flaherty M., Rutkowski M. i wsp. A victory for statins or a defeat for diet policies? Cholesterol falls in Poland in the past decade: a modeling study. Int. J. Cardiol. 2015; 185: 313-319.

6. Reiner Ž., Catapano A.L., De Backer G. i wsp. Grupa Robocza do spraw postępowania w dyslipidemiach Europejskiego Towarzystwa 
Kardiologicznego (ESC) i Europejskie Towarzystwo Miażdżycowe (EAS). Wytyczne ESC/EAS dotyczące postępowania w dyslipidemiach. Kardiol. Pol. 2011; 69: 143-200.

7. Fulcher J., O'Connell R., Voysey M. i wsp. Efficacy and safety of LDL-lowering therapy among men and women: meta-analysis of individual data from 174,000 participants in 72 randomized trials. Lancet 2015; 385: 1397-1405.

8. Wożakowska-Kapłon B. Terapia hipercholesterolemii w schorzeniach układu sercowo-naczyniowego - jaki cel, jaka statyna, jaka dawka? Folia Cardiol. 2014; 9: 55-66.

9. Kapłon-Cieślicka A., Filipiak K. Leczenie hipercholesterolemii w warunkach ambulatoryjnych w Polsce. Choroby Serca Nacz. 2015; 12: $240-248$.

10. Mathews R., Wang T.Y., Honeycutt E. i wsp. Persistence with secondary prevention medications after acute myocardial infarction: insights from the TRANSLATE-ACS study. Am. Heart J. 2015; 170: 62-69.

11. De Vera M.A., Bhole V., Burns L.C., Lacaille D. Impact of statin adherence on cardiovascular disease and mortality outcomes: a systematic review. Br. J. Clin. Pharmacol. 2014; 78: 684-698.

12. Nielsen S.F., Nordestgaard B.G. Negative statin-related news stories decrease statin persistence and increase myocardial infarction and cardiovascular mortality: a nationwide prospective cohort study. Eur. Heart J. 2016; 37: 908-916.

13. Starzyk K., Wożakowska-Kapłon B. Objawy mięśniowe w przebiegu stosowania statyn - fakty, mity, rzeczywistość i stanowiska ekspertów. Folia Cardiol. 2015; 10: 354-360.

14. Bays H., Cohen D.E., Chalasani N. i wsp. An assessment by the Statin Liver Safety Task Force: 2014 update. J. Clin. Lipidol. 2014; 8: S47-S57.

15. de Zeeuw D., Anzalone D.A., Cain V.A. i wsp. Renal effects of atorvastatin and rosuvastatin in patients with diabetes who have progressive renal disease (PLANET I): a randomised clinical trial. Lancet Diabetes Endocrinol. 2015; 3: 181-190.
16. Savarese G., Musella F., Volpe M. i wsp. Effects of atorvastatin and rosuvastatin on renal function: a meta-analysis. Int. J. Cardiol. 2013; 167: 2482-2489.

17. Plakogiannis R., Cohen H. Optimal low-density lipoprotein cholesterol lowering - morning versus evening statin administration. Ann. Pharmacother. 2007; 41: 106-110.

18. Filipiak K.J., Walczewski M. Dawki pośrednie rosuwastatyn w praktyce klinicznej - od teorii, przez EBM, do wskazówek terapeutycznych. Choroby Serca Nacz. 2015; 12: 8-14.

19. Zdrojewski T., Jankowski P., Bandosz P. i wsp. Nowa wersja systemu oceny ryzyka sercowo-naczyniowego i tablic SCORE dla populacji Polski. Kardiol. Pol. 2015; 73: 958-961.

20. Perk J., Backer G., Gohlke H. i wsp. Europejskie wytyczne dotyczące zapobiegania chorobom serca i naczyń w praktyce klinicznej na 2012 rok. Kardiol. Pol. 2012; 70 (supl. I): S1-S100.

21. Myśliwiec M., Walczak M., Małecka-Tendera E. i wsp. Management of familial hypercholesterolemia in children and adolescents: position paper of the Polish Expert Forum. J. Clin. Lipidol. 2014; 8: 173-180.

22. Cannon C.P., Blazing M.A., Giuliano R.P. i wsp.; IMPROVE-IT Investigators. Ezetimibe added to statin therapy after acute coronary syndromes. N. Engl. J. Med. 2015; 372: 2387-2397.

23. Boekholdt S.M., Hovingh G.K., Mora S. i wsp. Very low levels of atherogenic lipoproteins and the risk for cardiovascular events: a metaanalysis of statin trials. J. Am. Coll. Cardiol. 2014; 64: 485-494.

24. Nicholls S.J., Brandrup-Wognsen G., Palmer M. i wsp. Meta-analysis of comparative efficacy of increasing dose of atorvastatin versus rosuvastatin versus simvastatin on lowering levels of atherogenic lipids (from VOYAGER). Am. J. Cardiol. 2010; 105: 69-76.

25. Brus S. Clinical evidence of the efficacy of Krka's rosuvastatin in the treatment of hyperlipidemia with focus on additional doses. Krka Med. Farm. 2014; 26: 62-71. 